\title{
KONSEP MEMAYU HAYUNING BAWANA: ANALISIS HERMENEUTIKA PADA PUISI-PUISI SAPARDI DJOKO DAMONO
}

\author{
Heri Isnaini \\ Program Studi Pendidikan Bahasa dan Sastra Indonesia \\ Fakultas Pendidikan Bahasa - IKIP Siliwangi Cimahi \\ Surel: heriisnaini1985@gmail.com
}

\begin{abstract}
Abstrak
Artikel ini membahas konsep memayu hayuning bawana pada puisi-puisi karya Sapardi Djoko Damono. Konsep memayu hayuning bawana merupakan salah satu konsep ajaran mistik Jawa yang bertujuan membangun keseimbangan, kesadaran, dan kelestarian alam. Konsep ini dapat juga dimaknai sebagai rahmatan lil alamin, yakni menjadikan manusia bermanfaat bagi sesama dan alam. Konsep ini juga bertujuan mencapai keselarasan mikrokosmos dan makrokosmos, yakni keselarasan hubungan manusia dengan Tuhan, hubungan manusia dengan manusia, dan hubungan manusia dengan alam. Teori yang digunakan pada pembahasan ini adalah teori hermeneutika Paul Ricoeur dengan memfokuskan pada pembahasan kode-kode simbolik yang terkait dengan kerangka konsep memayu hayuning bawana. Metode yang digunakan dalam penelitian ini adalah metode kualitatif dengan menggunakan tahapan-tahapan dalam konsep hermeneutika Paul Ricouer, yakni diawali dengan objektifikasi struktur teks, mengklasifikasi kode-kode simbolik, menafsirkan kodekode simbolik, memaknai teks sesuai kerangka konsep mistik Jawa, dan mengaitkan teks yang memiliki relasi dengan teks yang lain. Dengan demikian, hasil penelitian ini dapat menunjukkan konsep memayu hayuning bawana dalam puisi-puisi Sapardi Djoko Damono sebagai bentuk ideologi yang digunakan penyair dalam merepresentasikan gagasan dalam bentuk puisi.
\end{abstract}

Kata Kunci: konsep memayu hayuning bawana, hermeneutika, puisi, stilistika

\section{Jurno Abstract}

Pendidikan Bahasa, Sastra

This article discusses the concept of "memayu hayuning bawana" in Sapardi Djoko Damonos poetries. The concept of "memayu hayuning bawana" is one of the concepts of Javanese mystical teachings aimed at building balance, awareness, and preservation of nature. This concept can also be interpreted as "rahmatan lil alamin", which is to make humans useful for others and nature. This concept also aims to achieve harmony between the microcosm and the macrocosm, namely the harmony of human relations with God, human relations with humans, and the relationship between humans and nature. The theory used in this discussion is Paul Ricoeur's hermeneutic theory by focusing on the discussion of symbolic codes related to the concept framework of "memayu hayuning bawana". The method used in this research is qualitative method by using stages in Paul Ricouer's 
hermeneutic concept, namely beginning with objectification of text structure, classifying symbolic codes, interpreting symbolic codes, interpreting text in accordance with javanese mystical concept framework, and associating text that has relationship with other texts. Thus, the results of this study can show the concept of memayu hayuning bawana in the poems of Sapardi Djoko Damono as a form of ideology used by poets in representing ideas in the form of poetry.

Keywords: the concept of "memayu hayuning bawana", hermeneutics, poetry, stylistics

\section{PENDAHULUAN}

Memayu hayuning bawana merupakan ajaran orang Jawa agar menjaga kelestarian alam, menjaga kedamaian hidup dengan sesama, menjaga keseimbangan, serta meninggalkan perbuatan-perbuatan tercela yang bisa mengganggu kenyamanan hidup orang lain. Manusia harus mengerjakan perbuatan terpuji dan menghindarkan diri dari perbuatan tercela. Konsep ini sesungguhnya adalah pengajaran tentang keseimbangan alam. Hubungan yang baik antara alam dan manusia. Menurut Endraswara (2016a: 128) keseimbangan tersebut dimaknai sebagai harmoni. Harmoni manusia dengan alam akan menciptakan suasana yang tenang, damai, dan aman.

Bagi masyarakat Jawa, harmoni dan selaras adalah konsep metafisis yang menjiwai seluruh gerak dan dinamika masyarakat. Hal ini sesuai dengan penjelasan Mulder (2001a:17) yang menjelaskan bahwa hakikat citacita masyarakat Jawa adalah menuju keharmonisan dan keselarasan (memayu hayuning bawana).

Nilai-nilai yang menjadi patokan dalam mewujudkan keharmonisan dan keselarasan ini adalah rukun dan rasa hormat. Menurut Geertz (1992: 45) fondasi dalam membentuk keselarasan dan keharmonisan masyarakat Jawa adalah prinsip rukun dan hormat.
Sementara, Harini (2019: 201-202) menjelaskan keselarasan dan keharmonisan terikat secara mutlak dari hubungan antarmanusia dan hubungan dengan Tuhan.

Habermas (Fithri, 2014: 192) berpendapat untuk memahami hermeneutika harus terlebih dahulu memahami maksud dari penjelasan dan pemahaman. Penjelasan menuntut penerapan teori terhadap fakta, sedangkan pemahaman adalah suatu kegiatan yang menggabungkan pengalaman dan teori menjadi satu.

Sementara itu, Aristoteles (B.S., 2006: 199) menjelaskan kata-kata yang diucapkan adalah simbol dari pengalaman mental dan kata-kata yang ditulis adalah simbol dari kata-kata yang diucapkan. Sementara itu, Paul Ricoeur (Saidi, 2008: 378-379) menjelaskan dalam proses penafsiran, iqangkah-langkah yang dapat digunakan adalah sebagai berikut.

1. Teks ditempatkan sebagai objek yang diteliti sekaligus sebagai objek atau pusat yang otonom.

2. Teks dipahami dengan cara mengobjektivasi strukturnya.

3. Lapis simbolisasi.

4. Penafsiran kode-kode simbolik.

5. Mengaitkan kode-kode simbolik dengan hal-hal di luar dirinya.

6. Pemaknaan teks. 
Pembahasan pada puisi-puisi karya Sapardi Djoko Damono didasarkan pada argumentasi yang dikemukakan oleh Mahayana (2015: 14) yang mengatakan bahwa puisi Sapardi Djoko Damono tidak semata ekspresi perasaan hati, melainkan pergulatan estetis dan tarik-menarik gejolak perasaan yang melimpah dan yang harus terintegrasi dengan pemikiran dan kualitas intelektual. Intelektualitas yang diusung Sapardi dalam proses kreatifnya tersebut yang menjadikan puisi-puisi Sapardi Djoko Damono menjadi menarik untuk dibahas.

Sementara itu, Isnaini (2020) mengatakan bahwa puisi-puisi yang ditulis Sapardi Djoko Damono cenderung puisi-puisi yang imajisintelektual, yakni adanya perpaduan antara pikiran, perasaan, dan emosi yang menyatu dalam struktur terdalam dalam puisi-puisinya. Dengan demikian, di dalamnya ada gagasan-gagasan yang menunjukkan bahwa karya sastra (dalam hal ini puisi) tidak bersifat otonom. Artinya, selalu ada keterkaitan antara puisi karya sastra dengan halhal lain (Isnaini, 2012). Berdasarkan penjelasan tersebut, artikePenini mengejawantah penelitian atas puisi-puisi karya Sapardi Djoko Damono yang diindikasi memiliki gagasan-gagasan lain terkait konsep memayu hayuning bawana.

\section{METODE}

Artikel ini akan dianalisis berdasarkan konsep penelitian kualitatif. Data yang disajikan berupa teks tertulis berbentuk puisi. Metode penelitian ini menggunakan konsep hermeneutika Paul Ricoeur dengan memfokuskan pada penafsiran tanda dan kode-kode simbolik teks puisi. Tahapan-tahapan yang dilakukan dalam penelitian ini mengikuti enam tahapan, yaitu sebagai berikut.

Pertama, menggambarkan sturktur teks puisi sebagai sebuah bangunan teks yang otonom dan utuh. Kedua, mengobjektivasi struktur teks puisi dilihat dari bentuk teks, majas, bunyi, dan tema. Ketiga, mengklasifikasi lapis simbolisasi dan kode-kode simbolik. Keempat, penafsiran kode-kode simbolik yang terdapat pada teks. Kelima, mengaitkan kode-kode simbolik dengan hal-hal di luar dirinya. Keenam, memaknai teks sesuai dengan konsep yang dominan di dalam teks puisi dengan dikerangkai konsep mistik Jawa, yakni memayu hayuning bawana.

\section{HASIL DAN PEMBAHASAN}

Pembahasan makna memayu hayuning bawana merupakan ajaran mistik Jawa dalam menjaga kelestarian alam, menjaga kedamaian hidup dengan sesama, menjaga keseimbangan, serta meninggalkan perbuatan-perbuatan tercela yang bisa mengganggu kenyamanan hidup orang lain.

Tiga strategi pokok untuk mencapai memayu hayuning bawana (1) strategi mengolah diri pribadi, olah batin, dan olah rasa; (2) strategi interaksi sosial; dan (3) strategi interaksi dengan Tuhan (Endraswara, 2016b: 25). Strategistrategi tersebut memiliki tujuan untuk menjaga harmonisasi kosmos alam sehingga alam menjadi tenteram dan lestari. Pembahasan mengenai konsep ini akan dilihat pada diksi yang memiliki makna simbolik terkait konsep mistik memayu hayuning bawana. 
Diksi pertama yang akan dibahas pada bagian ini adalah diksi angin. Diksi angin akan banyak disandingkan dengan diksi-diksi alam yang lain terkait dengan relevansinya terhadap pola-pola kesimbangan kosmos. Pada puisi "Angin Pagi” dalam antologi puisi DukaMu Abadi (Damono, 1969: 27) dan Mata Jendela (Damono, 2001: 19) konsep memayu hayuning bawana ditandai dengan diksi-diksi alam, seperti: angin pagi, surya, dingin, memijar, dan sebagainya. Diksi-diksi ini menjadi bagian dalam membangun suasana pagi yang indah.

merendah angin pagi yang dingin

Suara yang dingin

surya yang masih juga Hidup aliasnya

memijar, berpijar-pijar di antara bulubulu mata

\section{(Damono, 1969: 27)}

Puisi tersebut menggambarkan suasana pagi yang dingin sehigga "suara" pun terasa dingin, tetapi suasana tersebut tetap hidup karena ada surya yang masih senantiasa berpijar, terlihat memijar. Dengan demikian, ada keseimbangan antara dingin diimbangi dengan surya yang memijar.

Penggambaran yang berbeda digambarkan pada puisi "Layanglayang" yang ditulis dalam antologi Arloji (Damono, 1998: 20) dan Ayat-s Ayat Api (Damono, 2000: 65). Diksidiksi yang ditulis dalam puisi ini adalah: layang-layang, angin, benang, kertas, potongan bambu, siang, sore, angkasa, melayang. Diksi-diksi tersebut membentuk satu kesatuan yang padu, yakni membentuk konsep layanglayang.

Layang-layang barulah layang-layang jika ada angin memainkannya. Sementara terikat pada benang panjang,

ia tak boleh diam - menggeleng ke kiri ke kanan, menukik, menyambar, atau menghindar dari layang-layang lain

(Damono, 1998: 20)

Bait tersebut menunjukkan bahwa layang-layang memiliki ciri khas khusus agar disebut dengan layanglayang. Penggambaran tersebut juga menggambarkan bahwa hidup yang baik adalah hidup seperti layanglayang. Ada keseimbangan. Layanglayang barulah layang-layang jika ada angin memainkannya. Pun juga manusia akan disebut manusia kalau ada Tuhan yang berkehendak. Dengan kata lain, ada keseimbangan di dalam kehidupan manusia.

Ia suka gemas pada angin. Ia telah menghayati sentuhan, terpaan, dan bantingannya; mungkin itu tanda

bahwa ia telah mencintainya. Ia

barulah layang-layang jika

melayang, meski tak berhak

membayangkan wajah angin.

(Damono, 1998: 20)

Keseimbangan yang dimaksud adalah keselarasan kosmos. Semesta harus aseimbang antara mikrokosmos dan makrokosmos. Keseimbangan tersebut digambarkan antara peran angin dan layang-layang, keduanya membangun keseimbangan sehingga dapat melayang dan terbang.

Konsep memayu hayuning bawana seperti penjelasan sebelumnya bahwa secara etimologis dari kata hayu-ayu (cantik); bawana (dunia). Persepsi orang Jawa bahwa dunia itu cantik dan indah sehingga harus dijaga dan 
dilindungi dengan cara paling baik. Cantik dan indahnya dunia atau alam ditandai dengan keindahan panorama pada tempat tertentu. Seperti pada puisi "Ayat-ayat Tokyo" dalam antologi Arloji (Damono, 1998: 23) dan AyatAyat Api (Damono, 2000: 71) keindahan ditandai dengan suasana keindahan alam dan kebersahajaan rasa.

\section{/11}

angin memahatkan tiga patah kata

di kelopak sakura-

ada yang diam-diam membacanya

121

ada kuntum melayang jatuh

air tergelincir dari payung itu

"kita bergegas", katanya

\section{/3/}

kita pandang daun bermunculan

kita pandang daun berguguran

kita diam: berpandangan

(Damono, 1998: 20)

Kebersahajaan puisi tersebut menyiratkan keharmonisan alam yang tergambar. Bahasa yang digunakan menggambarkan keindahan, dari penulisan pun tidak ditemui penggunaan huruf kapital. Hal ini menandakan adanya keharmonisan dan keseimbangan yang berusaha digambarkan pada puisi tersebut. Bait ketiga memperjelas konsep ini, /daun bermunculan//daun berguguran/ keduanya tetap menjadi seimbang, tidak ada yang gugur sebenarnya. Hanya ada kita (manusia) yang diam, saling berpandangan. Berkaitan dengan hal tersebut Mulder (2001b: 59) medefinisikan bahwa memayu hayuning bawana adalah norma ideal menuju kehidupan nyata. Norma ideal yang dimaksud oleh Niels Mulder tersebut adalah keseimbangan dan

keharmonisan alam.

Norma ideal tersebut digambarkan pada puisi "Sarang" dalam antologi Mata Jendela (Damono, 2001: 87), penggunaan simbol-simbol pancaindra: pendengaran, penglihatan, perasa menjadi bentuk yang mengacu pada keseimbangan. Keseimbangan inilah yang mampu mewujudkan keindahan alam ini. Berikut disajikan puisi "Sarang" secara lengkap.

kaudengarkah suara angin yang mencari sarangnya?

kaulihatkah gelengan pohon setiap kali ia ditanya?

kau rupanya memang tak mampu

membayangkan

betapa indah dan sia-sianya setiap

pencarian

(Damono, 2001: 87).

Setelah pancaindra sudah mampu menyeimbangkan keberadaan alam yang kosmis maka semua akan menjadi sangat indah dan setiap pencarian apa pun adalah sia-sia. Mengapa sia-sia? Karena pencarian sejatinya harus di dalam diri, dalam kesadaran diri. Inilah inti dari keseimbangan itu. Sikap memayu hayuning bawana seyogyanya dimulai dari menata keseimbangan diri, mikrokosmos. Dengn demikian, tatanan yang lebih besar dapat dibuat menjadi harmonis.

Keharmonisan hanya akan tercapai jika ada komposisi yang seimbang. Komposisi merupakan susunan, gubahan, atau integrasi warna, garis, dan bidang untuk mencapai kesatuan yang harmonis. Harmonisasi ini yang digambarkan dalam puisi "Hujan Dalam Komposisi, 1", "Hujan Dalam Komposisi, 2", dan "Hujan Dalam Komposisi, 3". Puisi-puisi tersebut ada 
dalam antologi Mata Pisau (Damono, 1974: 13, 14, 15) dan Hujan Bulan Juni (Damono, 1994: 28, 29, 30). Ketiga puisi tersebut menggambarkan hubungan kosmis antara manusia dan alam. Puncak dari harmonisasi tersebut adalah kesadaran kepada Tuhan.

Pada puisi yang pertama, komposisi itu ditunjukkan dengan hujan yang "dinikmati" dari balik jendela sehingga hujan dinikmati adalah suaranya. "Apakah yang kautangkap dari suara hujan, dari daun-daun bugenvil basah yang teratur mengetuk jendela?" Hujan sangat harmonis yang ditandai dengan keharmonisan hubungan antara tanah dan hujan atau hubungan antara daun basah dan ketukan di jendela?

Ia membayangkan hubungan gaib

antara tanah

dan hujan, membayangkan rahasia

daun basah

serta ketukan yang berulang

(Damono, 1974: 13)

Komposisi yang digambarkan dengan indra pendengaran dan perasaan ini menghasilkan harmonisasi dalam memaknai hujan yang sangat ritmis. Pada puisi yang kedua, harmonisasi tunjukkan dengan komposisi terjadinya hujan dalam puisi ini lohujan digambarkan dengan "mula-mula ia udara tinggi, ringan dan bebas; lalu mengkristal dalam dingin; kemudian melayang jatuh ketika tercium bau bumi; tergelincir dari daun-daun (bait 1), dan tergelincir masuk selokan kecil, terus mericik juda di dalam gelap ini, bercakap tentang lautan (bait 2). Komposisi dalam siklus air ini digambarkan dalam puisi "Hujan Dalam Komposisi, 2".
Komposisi yang ditampilkan dalam puisi "Hujan Dalam Komposisi, 3" dalam suasana hening dan sunyi. Keheningan dan kesunyian ini digambarkan dengan bunyi tik-tok jam.

dan tik-tok jam itu kita indra kembali akhirnya:

terpisah dari hujan

(Damono, 1974: 15)

Keheningan dan kesunyian menjadi komposisi yang penting pada konsep keterpisahan. Berpisah bermakna sunyi. Artinya, ketika bunyi tik-tok jam sudah terdengar berarti hujan yang suaranya berulang dalam ketukan ritmis di jendela sudah tiada. Itulah bentuk-bentuk keseimbangan dan harmonisasi digambarkan dalam komposisi hujan.

Asal usul penciptaan alam semesta dinyatakan dengan tiga unsur semesta: bumi lan langit, cahya lan teja, dan manikmaya. Ketiga unsur semesta tersebut sama-sama merupakan emanasi dari Hyang Wisesaning Tunggal (Dumadi, 2011: 2-3). Keselarasan manusia dengan alam semesta yang diistilahkan dengan jumbuhing jagad cilik lan jagad gedhe atau bersatunya mikrokosmos dan makrokosmos. Keharmonisan tersebut dapat digambarkan dengan berbagai komposisi, seperti komposisi keselarasana lam. Pada puisi "Kuhentikan Hujan" dalam antologi Sihir Hujan (Damono, 1984: 8) dan Hujan Bulan Juni (Damono, 1994: 82) keselarsan tersebut ditandai dengan diksi hujan, matahari, kabut, tanah, cahaya, dan bunga-bunga.

Tak bisa kutolak matahari memaksaku menciptakan bunga-bunga

(Damono, 1984: 8) 
Bait terakhir pada puisi tersebut menunjukkan bahwa keseimbangan dapat dimaknai sebagai harmonisasi antara matahari, aku, dan bunga. Harmonisasi yang dimaksdukan dalam mistik Jawa sebagai bumi lan langit, cahya lan teja, dan manikmaya atau jumbuhing jagad cilik lan jagad gedhe.

Analogi tanaman seperti proses kehidupan manusia seperti yang telah dibahas pada makna sangkan paraning dumadi, merupakan ajaran mistik Jawa tentang ajaran kesadaran akan kekuatan Tuhan dan harmonisasi kehidupan. Tanaman mati kemudian tumbuh kembali melalui benih, akar, batang, daun, bunga, buah, dan berlulang-ulang seterusnya. Tanaman menjadi analogi yang baik dalam menumbuhkan kesadaran kepada manusia.

Kehidupan manusia akan terus berlanjut dalam diri anak-anaknya setelah mereka tiada. Dengan demikian, konsep tanaman menjadi inti dalam proses pembelajaran itu. Selain itu, tanaman menjadi tanda keseimbangan kosmos. Puisi-puisi berikut menggambarkan tanaman (pohon) yang menyimpan konsep mistik Jawa memayu hayuning bawana.

Pada puisi "Tentang Pohon, 1" dalam antologi Mata Jendela (Damono, 2001: 79) pohon digambarkan sebagai pusat dari kehidupan, dia tidak pernah meninggalkan tempatnya tumbuh dan menjadi rumah bagi burung-burung. Pohon yang senantiasa mencintai angin yangtidak terlihat yang entah datang dari mana. Konsep pohon ini menggambarkan simbol keteguhan dan kekokohan sehingga dapat bermanfaat bagi yang lain.

pohon, yang tak pernah ingin mengembara, yang setia membasuh butir demi butir

udara,

telah jatuh cinta kepada angin, yang

rumahnya di angkasa,

yang kepak sayapnya selalu penuh

burung gereja

(Damono, 2001: 79)

Pentingnya keberadaan pohon dalam siklus hidup dan kehidupan semua makhluk ditegaskan dalam puisi "Tentang Pohon, 2" dan "Tentang Pohon, 3" (Damono, 2001: 80-81). Pohon menjadi sangat penting sehingga harus dilestarikan sebagai bagian dari menjaga alam dan upaya memayu hayuning bawana. Pohon tidak boleh seenaknya ditebang tanpa sebab karena tanpa rimbunan pohon apakah akan ada kehidupan? Manusia dan makhluk yang apa pun bergantung pada pohon, bahkan di dalam kepercayaan tradisional, pohon juga menjadi tempat bagi makhluk gaib. Dengan demikian, kelestariannya harus tetap dijaga. Damono menegaskan hal ini dalam larik-larik berikut.

seandainya pohon ini kita relakan saja dalam upacara korban kapak dan gergaji

di teduh rimbun mana pula bisa menjelma manusia kembali (Damono, 2001: 80)

\section{Ran Bahasa, Sart}

Upaya membangun kesadaran bahwa pohon menjadi bagian dalam kesimbangan kosmis sehingga harmonisasi alam dapat terus lestari adalah dengan cara merawat dan menghargai pohon sebagaimana menghargai luluhur.

Pada puisi "Pokok Kayu" dalam antologi Ayat-Ayat Api (Damono, 2000: 111) pohon digambarkan sebagai awal 
kehidupan karena tanpa pohon tidak akan terjadi keseimbangan.

\section{"suara angin di rumpun bambu} dan suara kapak di pokok kayu, adakah bedanya, Saudaraku?"

\section{“jangan mengganggu”, hardik seekor tempua}

yang sedang mengerami telur-telurnya di kusut rambut Nuh yang sangat purba (Damono, 2000: 111)

Pada puisi tersebut setidaknya ada 2 unsur, pertama angin dan pohon serta unsur kedua adalah tempua dan Nuh. Kedua unsur ini menjalin dalam kerangka menggambarkan proses keseimbangan alam. Puisi ini ditulis dalam benuk terzina dengan rima akhir yang sangat teratur. Pada bait 1 ada pertanyaan retoris tentang suara rumpun bambu dan pohon yang ditebang. Apakah ada perbadaan suara pada keduanya? Pertanyaan ini dijawab dengan "jangan mengganggu". Artinya, bait ini dapat dimaknai sebagai bentuk pengingkaran terhadap kerusakan alam (baca: pohon). Pohon harus lestari tidak boleh ditebang dengan alasan apa pun, hardik tempua. Penggunaan tempua, seekor burung yang pandai mengayam sarang, menjadi penegas bahwa alam harus lestari. Penegasan ini diakhiri dengan larik /di kusut rambut Nuh yang sangat purba/. Dengan demikian, sudah jelas bahwa keseimbangan yang diharapkan adalah keseimbangan yang hakiki antarunsur pembentuknya, terutama pohon.

Kritik terhadap unsur-unsur pembentuk dalam kesimbangan ini terdapat pada puisi "Pohon di Tepi Jalan" dalam antologi Arloji (Damono, 1998: 38) Ayat-Ayat Api (Damono, 2000: 103) diksi pohon dan tiang listrik menjadi bentuk kritik terhadap konsep ini. Tiang listrik yang berdiri gagah di tepi jalan seolah menjadi pengganti pohon. Tiang listrik tidak perlu disiram dan dia teman yang baik untuk asap knalpot dari mobil tua. Walaupun demikian, tiang listrik tidak dapat menggantikan fungsi pohon yang dapat mengubah asap knalpot dari mobil tua itu menjadi sumber kehidupan manusia. Puisi ini dengan tajam mengkritik keberadaan pohon-pohon di kota yang notabene menjadi sumber udara bagi kehidupan tidak dijaga sebagaimana fungsi awalnya.

di bawah matahari; pohon, yang sudah lupa

asal-usulnya, suka menghirup asap

knalpot

dan menyebutnya kekasih, sumber

kehidupan kota;

kita tak pernah sempat memahami

kelakar mereka

(Damono, 1998: 38)

Diksi kekasih yang disebutkan oleh pohon menandakan bahwa pohon menjadi bagian penting dalam kehidupan manusia, terutama manusia di kota. Pohon ibarat seorang kekasih yang "mencintai dengan sederhana" tidak dalam keinginan untuk memperoleh imbalan, sepi ing pamrih, salah satu wujud implementasi memayu hayuning bawana.

\section{SIMPULAN}

Artikel ini menunjukkan konsep ajaran mistik Jawa, memayu hayuning bawana, dalam puisi-puisi Sapardi Djoko Damono. Konsep mistik ini adalah konsep yang fokus pada upaya melestarikan dan menjaga keseimbangan alam. Sehingga ada harmonisasi antara jagad cilik dan jagad 
gedhe atau mikrokosmos dan makrokosmos. Harmonisasi inilah yang menjadi puncak attas kebahagiaan manusia dalam kehidupan di dunia.

Konsep memayu hayuning bawana dapat dilihat dari diksi-diksi yang terdapat pada puisi-puisi Damono. Diksi-diksi tersebut mengejawantah dalam pola-pola ajaran yang menempatkan manusia menjadi tonggak dalam menjaga alam dan dunia ini. Diksi-diksi yang muncul, seperti diksi alam, pohon, angin, hujan, air, matahari, dan warna menjadi bagian dalam penafsiran makna ajaran ini.

Diksi-diksi tersebut dipahami dengan menggunakan teori hermenutika Paul Ricouer yang menempatkan puisi sebagai teks yang terbuka untuk dimaknai. Teori ini diterapkan dengan mengobjektivikasi teks, kemudian dicari kode-kode simbolik yang terkait dengan tema. Setelah itu, kode-kode simbolik tersebut dapat dimaknai dan diinterpretasi sesuai dengan data dan argumentasi teori.

Ajaran mistik Jawa, selain memayu hayuning bawana ada juga sangkan paraning dumadi dan manunggaling kawula Gusti, ketiganya menjadi dasar dalam mencapai tujuan menjadi "manusia sejati". Artikel ini hanya membahas satu dari tiga ajaran tersebut. Dengan demikian, ada kemungkinan penelitian lanjutan untuk mengenapi ajaran mistik Jawa, terutama dalam karya sastra.

\section{DAFTAR PUSTAKA}

B.S., A. W. (2006). Hermeneutika sebagai Sistem Interpretasi Paul Ricoeur dalam Memahami Teks-Teks Seni. Jurnal Imaji, Vol. 4, No.2, Agustus 2006, 198-209.
Damono, S. D. (1969). DukaMu Abadi. Jakarta: Pustaka Jaya.

Damono, S. D. (1974). Mata Pisau. Jakarta: Balai Pustaka.

Damono, S. D. (1984). Sihir Hujan. Kuala Lumpur: Dewan Bahasa dan Pustaka.

Damono, S. D. (1994). Hujan Bulan Juni. Jakarta: Gramedia-Grasindo.

Damono, S. D. (1998). Arloji. Jakarta: Yayasan Puisi.

Damono, S. D. (2000). Ayat-Ayat Api. Jakarta: Pustaka Firdaus.

Damono, S. D. (2001). Mata Jendela. Magelang: Indonesia Tera.

Dumadi, J. (2011). Mikul Dhuwur Mendhem Jero. Yogyakarta: Pura Pustaka.

Endraswara, S. (2016a). Ekologi Sastra. Yogyakarta: Caps.

Endraswara, S. (2016b). Метауи Hayuning Bawana: Laku Menuju Keselamatan dan Kebahagiaan Hidup Orang Jawa. Yogyakarta: Narasi.

Fithri, W. (2014). Kekhasan Hermeneutika Paul Ricoeur. Tajdid, Fakultas Ushuluddin, IAIN Imam Bonjol, Padang, Vol. 17, No.2, November 2014, 187-211.

Geertz, C. (1992). Kebudayaan dan Agama (F. B. Hardiman, Trans.). Yogyakarta: Kanisius.

Harini, S. (2019). Tasawuf Jawa. Yogyakarta: Araska.

Isnaini, H. (2012). Gagasan Tasawuf Pada Kumpulan Puisi Isyarat Karya n Bahas Kuntowijoyo. Semantik, 1(1).

Isnaini, H. (2020). Representasi Ideologi Jawa pada Puisi-Puisi Karya Sapardi Djoko Damono. Pena: Jurnal Pendidikan Bahasa dan Sastra, Vol. 10 No. 1 Juli 2020, 24-47.

Mahayana, M. S. (2015). Kitab Kritik Sastra. Jakarta: Yayasan Pustaka Obor Indonesia.

Mulder, N. (2001a). Mistisisme Jawa Ideologi di Indonesia (N. Cholis, 
Trans.). Yogyakarta: LKiS Saidi, A. I. (2008). Hermeneutika, Sebuah Yogyakarta.

Cara untuk Memahami Teks.

Mulder, N. (2001b). Ruang Batin

Masyarakat Indonesia (W.

Jurnal Sosioteknologi, Edisi 13,

Hardana, Trans.). Yogyakarta:

Tahun 7, April 2008, 376-382.

LKiS.

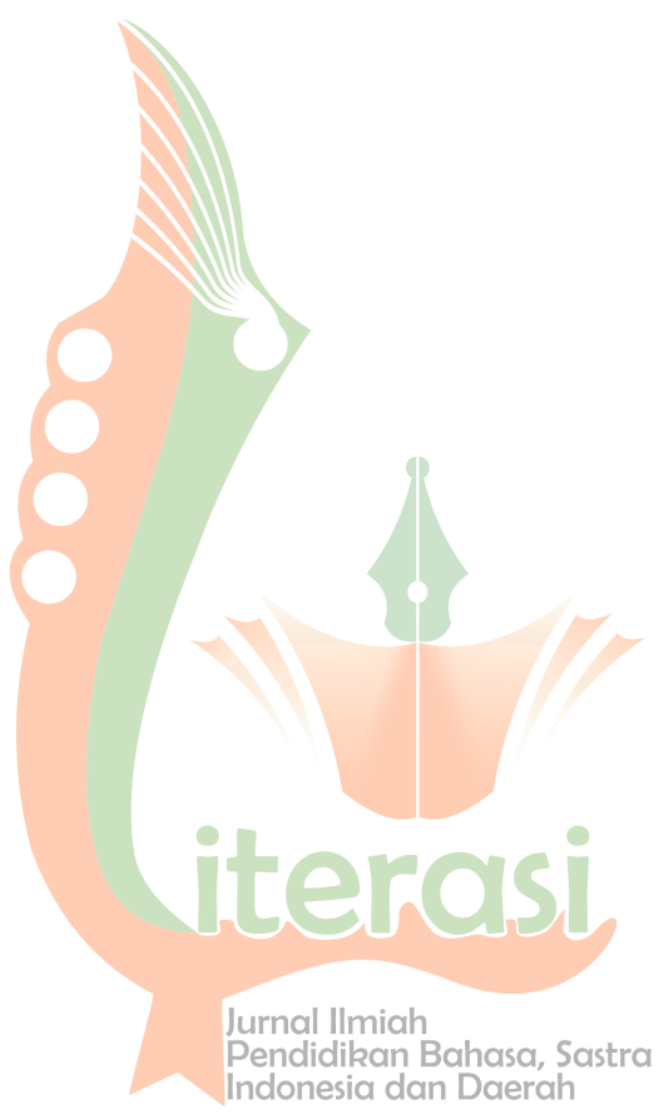

